\title{
Rehabilitation of Brougham Castle Bridge, UK
}

1 David Wiggins $B S c($ Hons), PhD, IEng, MICE Senior Conservation-Accredited Engineer, Curtins, Kendal, UK (corresponding author: david.wiggins@curtins.com)

2 Kiera Mudd MEng(Hons) Engineer, Curtins, Leeds, UK
3 Matthew Healey HNC, ONC

Contracts Director, Civil Engineering, Metcalfe Plant Hire Ltd, Penrith, UK
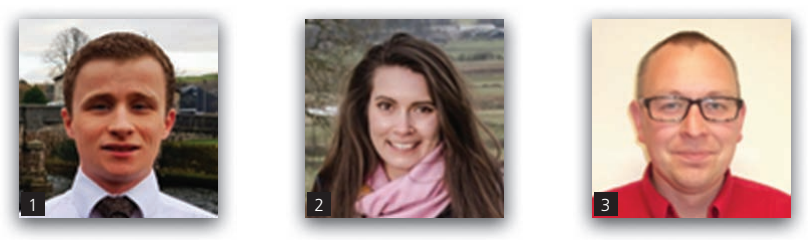

Brougham Castle Bridge is a three-span masonry arch highway bridge that has suffered significant scour damage to foundations and substructure with referred damage through the superstructure. This paper presents an engineer's account of the appraisal, investigation, assessment of structural action and the design and execution of repairs for stabilising the structure. The analytical tool employed to interpret the flow of force was a thrust-line graphical equilibrium analysis. It will be demonstrated that this analytical approach accords with the observed structural pathology, thus giving a clear understanding as to where the loads are going, that they may be effectively grappled with. Through thrust-line analysis, continued stability could be demonstrated despite substantial changes in the foundation conditions. It seems fitting that this efficient, robust and confidence-building tool is the same used by the engineers who originally designed many of these bridges. Using this 'historical approach', a successful intervention was executed; initially emergency stabilisation work to save the bridge from collapse and latterly permanent rehabilitation works to bring the bridge back into service in advance of the upcoming winter floods.

\author{
Notation \\ H horizontal force component \\ $h$ height \\ L length \\ M moment \\ $n \quad$ integer \\ $R_{\mathrm{V}} \quad$ resultant vertical force \\ $V \quad$ vertical force component \\ $W \quad$ weight \\ $x \quad$ horizontal distance \\ y vertical distance
}

\section{Introduction}

Brougham Castle Bridge was constructed between 1811 and 1813 as part of the turnpike road system strengthening links between Penrith and Appleby (Historic England, 2018a). It is a three-span masonry arch bridge, of a total crossing length of $43 \mathrm{~m}$, over the River Eamont on an 'S-bend' just downstream of the confluence between the River Eamont and the River Lowther. The build form is typical of that period (Ruddock, 2009), comprising mass stone block spread foundations, ashlar facing masonry to the piers and cutwaters containing a rough rubble core. Segmental voussoir arches spring from carved skewbacks atop ashlar capping slabs over the pier heads, with rubble and soil fill over, between traditional masonry spandrels and parapets. The stone is Red Permian Penrith Sandstone of typical characteristics: density
$2340 \mathrm{~kg} / \mathrm{m}^{3}$, compressive strength c. $100 \mathrm{~N} / \mathrm{mm}^{2}$ and porosity c. $10-15 \%$ (Cumbrian Stone, 2016).

The bridge is Grade II listed and interfaces with a Scheduled Ancient Monument, Brougham Castle, at its southern abutment, which is the site of the historic Roman fort Brocavum, from which Brougham takes its name (Historic England, 2018b). In the winter of 2015, Storm Desmond struck Cumbria, leading to widespread damage across the county's rich masonry heritage (McIntyre, 2018). The Cumbria Infrastructure Recovery Programme (CIRP) was established to tackle the problem, as presented by Mathews and Hardman (2017).

The damage mechanism at Brougham Castle Bridge is as follows

- constriction scour under extreme flow volume combining with local scour at the northern pier, which led to the undermining of the upstream cutwater

- subsequent collapse of the cutwater

- progressive collapse of approximately the upstream third of the pier and incoming arch barrels.

Figure 1 presents a view of the damaged bridge.

The rehabilitation project was commissioned through the CIRP on a design-and-build New Engineering Contract 3 basis, awarded 


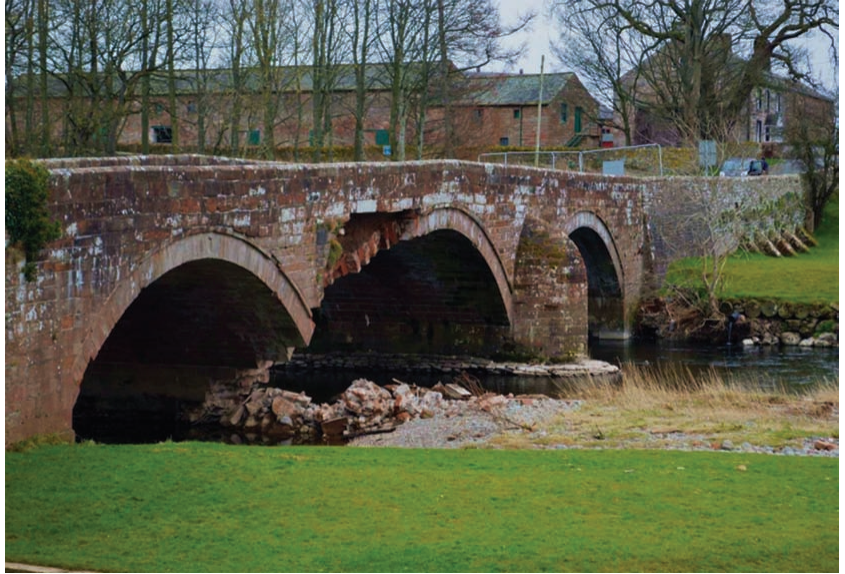

Figure 1. View of the damaged bridge from the northern bank looking south

to Metcalfe Plant Hire Ltd (Civil Engineering Division), who engaged Curtins as structural engineers. The project was undertaken in two stages - an initial temporary stabilisation followed by permanent rehabilitation works the following year.

The bridge was in a dangerous condition and presented significant safety challenges. It was closed to all public and traffic. Risks were assessed and managed on the basis of phased incremental working proximity, as unknowns were gradually removed and load paths were restored. Diagnosis of current and remaining load paths was central to managing risk. Real-time movement monitoring comprising vibration and tilt sensors attached to key elements of the bridge formed part of this approach. This ensured that construction activity did not worsen the structural condition and would give warning of further movement, were it to occur. Threshold values were determined as follows (BSI, 2007, 2009; Ciria, 1992)

- ruinous elements $-2 \mathrm{~mm} / \mathrm{s}$ peak particle velocity (PPV)

wider bridge $-10 \mathrm{~mm} / \mathrm{s}$ PPV

- $1^{\circ}$ of tilt for bodies of overhanging masonry.

\section{Appraisal of the damaged bridge}

A detailed visual structural condition appraisal was the first stage in assessment and yielded the following primary observations

(a) northern and southern abutments largely unaffected

(b) southern pier apparently unaffected

(c) southern arch span apparently unaffected

(d) central span segmental arch elevational geometry largely unaffected

(e) central span partial collapse of barrel on plan

$(f)$ northern arch span partial collapse of barrel on plan

$(g)$ northern cutwater collapsed, washed away

(h) northern pier laterally undercut down the northern flank and transversely undercut at the upstream end (i) apparent tilt of northern pier downwards in the upstream direction

(j) prominent crack along the bed joint at the springer of the northern arch as it bears onto the skewback on the pier

(k) prominent vertical crack up the remaining length of northern pier some $1.5 \mathrm{~m}$ back from the upstream face on the southern flank

(l) parapet flat-arching over the collapsed pier, crown to crown, spalling of arrises and evidence of longitudinal buckling observed under suspected high thrust.

Figure 2 presents a striking visual record of the bridge in the damaged state.

The bridge had seemingly halted in deterioration since the floodwaters subsided and in essence stood still for around 4 months until the time of assessment. It had self-evidently found a state of equilibrium with the change in support conditions. The objective of the structural condition appraisal was to determine the answers to the following questions.

Why was it still standing up?

- Where were the load paths going?

- What were the magnitudes of those loads?

- What was the remaining margin of safety under dead-load conditions?

Answers to these questions would inform the design of the temporary stabilisation work and execution strategy. A measured survey was initially made using photogrammetry. This recorded the physical geometry of the damaged bridge from which the stability assessment was then made. This informed the magnitude of the upstream lean of the pier, approximately $150 \mathrm{~mm}$ (cf. observation (i)). It was also revealed that the geometries of the incoming arch barrels did not fit round imperial numbers, suggesting some deformation, possibly historic and/or recent in activity. By comparison, the southern span fitted imperial units, implying that a proportion of the discord between metric and imperial geometries of the north and central spans was related to the damage to the pier.

An equilibrium assessment using traditional graphic statics (thrust lines and force vectors) was used to interpret the structural behaviour. Clearly, the damage occurs in three dimensions, so the problem was broken down and considered two-dimensional (2D) both on elevation/vertical section and on plan. The various outcomes were then reconciled to build a three-dimensional (3D) understanding of the bridge's structural behaviour.

\subsection{Introduction to thrust-line equilibrium analysis} Thrust-line analysis is based on three fundamental principles (Heyman, 1969).

- Masonry has unlimited compressive strength.

- Sliding between the masonry units does not occur.

- Masonry has zero tensile strength. 


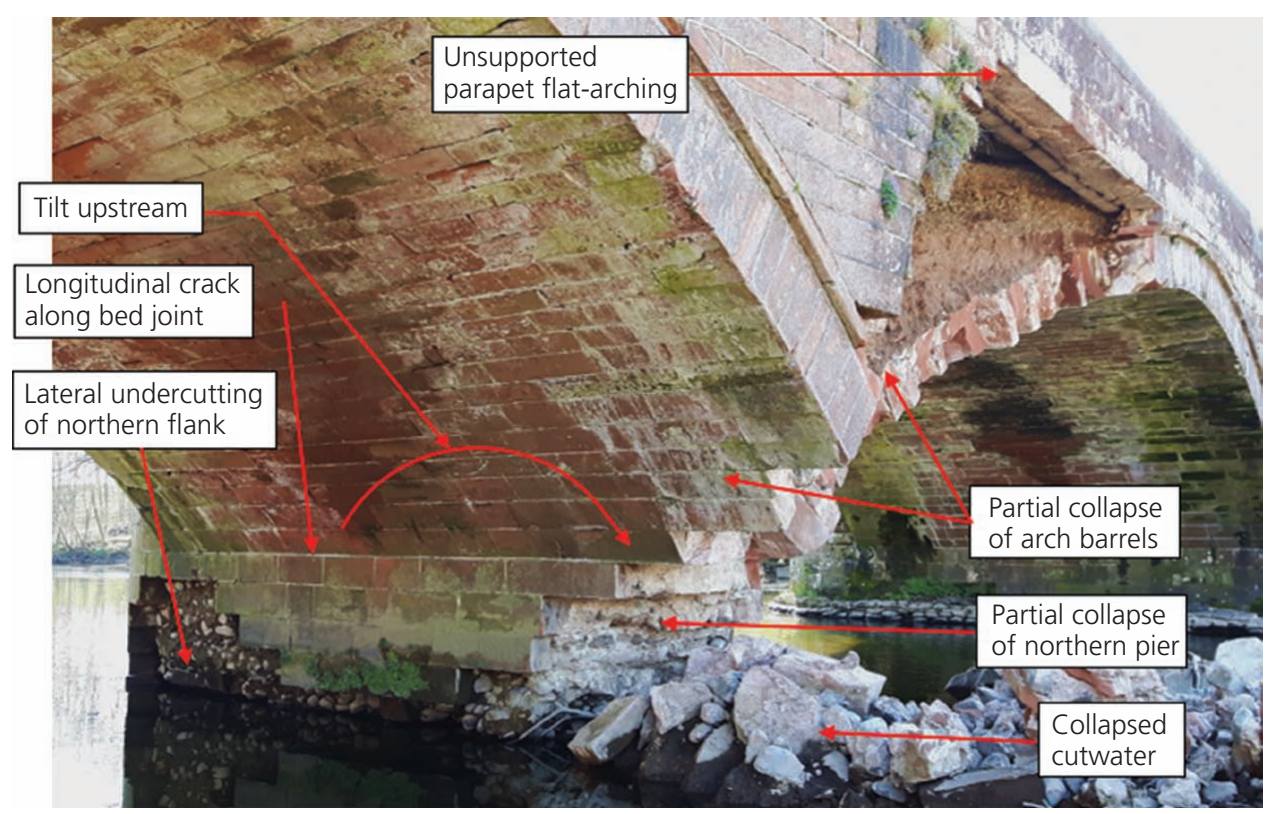

Figure 2. Brougham Bridge partial collapse of northern pier, viewed looking south

It is typical for masonry arches under dead loads to crack slightly at the crown (hinge opening towards the intrados) and at the springings (hinge opening towards the extrados), hence forming a three-pin statically determinate structure (Figure 3). The line of thrust passes through these hinges. The hinge locations can adjust to accommodate imposed load or to find support if damage is sustained. In order to calculate the line of thrust and its magnitude, funicular polygons can be drawn and the line of thrust plotted graphically. If the arch can be shown to have a valid load path which is contained entirely within the masonry, the structure is considered to be safe. The technique is described in detail by Heyman (1969, 1982, 1996).

One particular strength of this technique is that it does not require detailed knowledge of foundation conditions (Harvey, 2012a) which, particularly in this context, was unknowable at this stage.

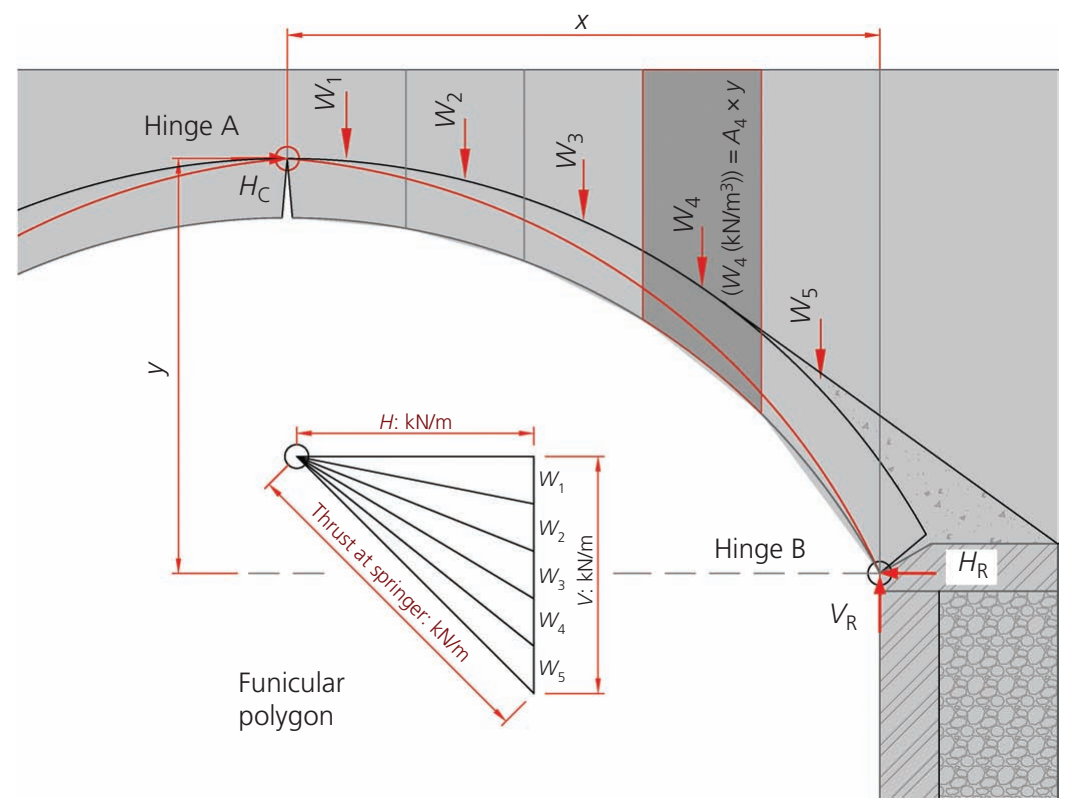

Figure 3. Thrust-line analysis of half-arch in minimum-thrust dead-load conditions 


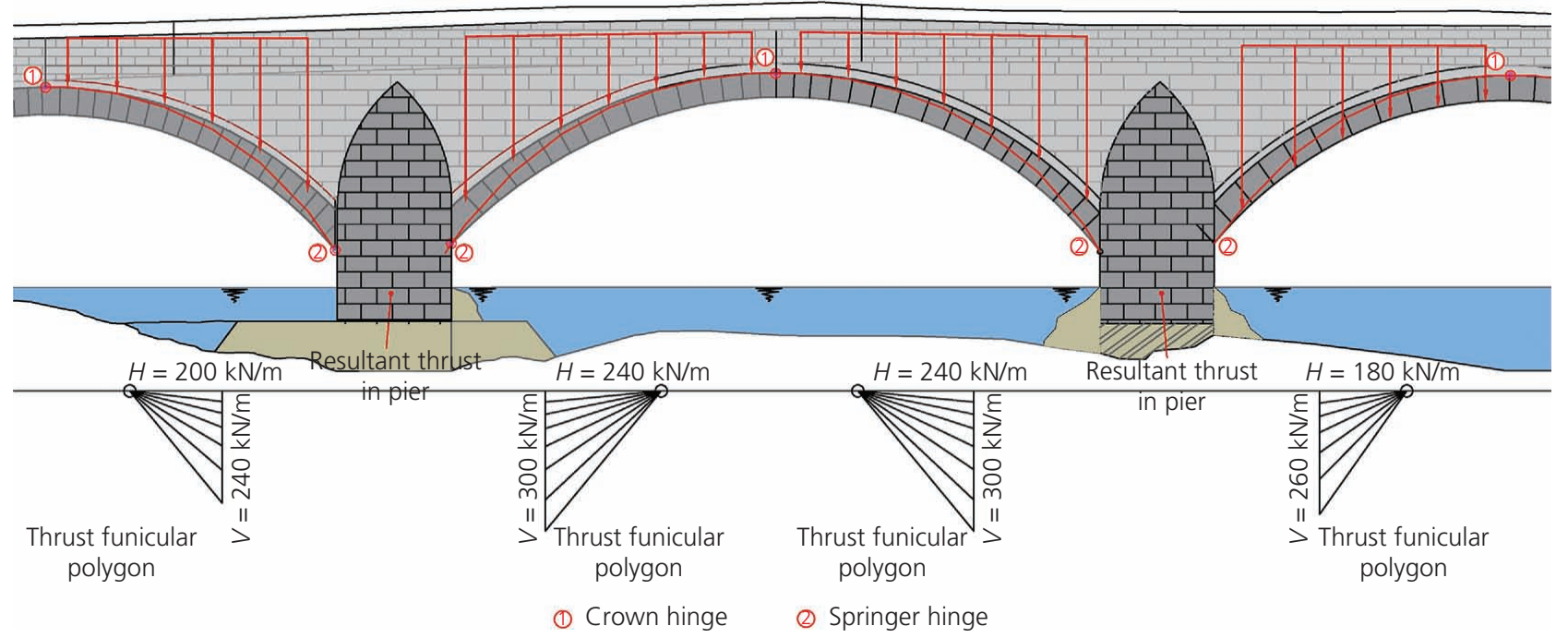

Figure 4. Longitudinal thrust-line analysis of thrust magnitudes in bridge

The method recognises the structural behaviour of historic masonry as an assemblage of dry-jointed masonry units, drawing strength and stability from its mass and geometrical form. In essence, this means that an arch barrel is fundamentally a thick, laterally loaded masonry wall curved about its axis. This qualitative understanding was central to structural diagnosis of the flow of force in the damaged state (Harvey, 2013).

Design information was determined as follows

- stone masonry density $23 \cdot 5 \mathrm{kN} / \mathrm{m}^{3}$

- fill density approximately $17 \mathrm{kN} / \mathrm{m}^{3}$

average estimate of masonry and fill combined density $c$. $21 \mathrm{kN} / \mathrm{m}^{3}$

- dead-load-only assessment conditions.

\subsection{Longitudinal stability}

To begin, the natural 'minimum-thrust' behaviour of the bridge was assessed in the undamaged original state, presented in Figure 4. The force components of thrusts on the northern pier were determined to be

1. $\sum M_{\text {crown }}=0$

where $H_{\mathrm{C}}=H_{\mathrm{R}}$ for equilibrium and $\Sigma V$ is known

$$
\begin{aligned}
0= & \sum\left[\left(W_{1} \times x_{1}\right)+\left(W_{2} \times x_{2}\right)+\left(W_{n} \times x_{n}\right)\right] \\
& \text { 2. } \quad+\left(H_{\mathrm{R}} \times y\right)-\left(V_{\mathrm{R}} \times x\right)
\end{aligned}
$$

left-hand (northern) arch: $H=200 \mathrm{kN} / \mathrm{m} ; V=240 \mathrm{kN} / \mathrm{m}$

right-hand (central) arch: $H=240 \mathrm{kN} / \mathrm{m} ; V=300 \mathrm{kN} / \mathrm{m}$
Introducing the observed defect of the lateral undercutting to the northern flank of the pier and in recognition of the crack at this position (opening of the bed joint along the springer block), the springer hinge was lifted and lengthened to reach further over the pier for the arch to find the support (Figure 5).

Note the presence of the stocky ashlar capping slab beneath the skewbacks (Figure 5(a)). This was judged to provide a stiff load path to accept the thrust from the arch barrel and spread it across the rubble fill core (Harvey, 2012b, 2013). This is an exception to the norm whereby the tightly jointed ashlar facing masonry carries the structural load, following the stiffest path $-c$. an order of magnitude stiffer than the lime-concrete rubble core (see the paper or Cassinello (2006)). The resolved thrust/counterthrust relationship between the incoming arches was assessed in a $2 \mathrm{D}$ section, as presented in Figure 5(b).

In vertical section/elevation, the pier and incoming arches were determined to be stable in the longitudinal direction by satisfactory resolution of thrusts.

\subsection{Plan stability}

Next, the observed defect of partial collapse of the northern pier was introduced. The behaviour of the incoming arches on plan was considered as follows.

- The nearside half of the central arch span was imagined as a masonry corbel (curved about its axis), loaded on top with a preload representing the horizontal thrust force component at the crown.

- The presence of the crack (cf. observation $(j)$ ) was introduced, and the idealised corbel dimensions are presented in Figure 6(a). The root cause of the crack $(j)$ was not conclusively proved although it was suspected as being local differential settlement 


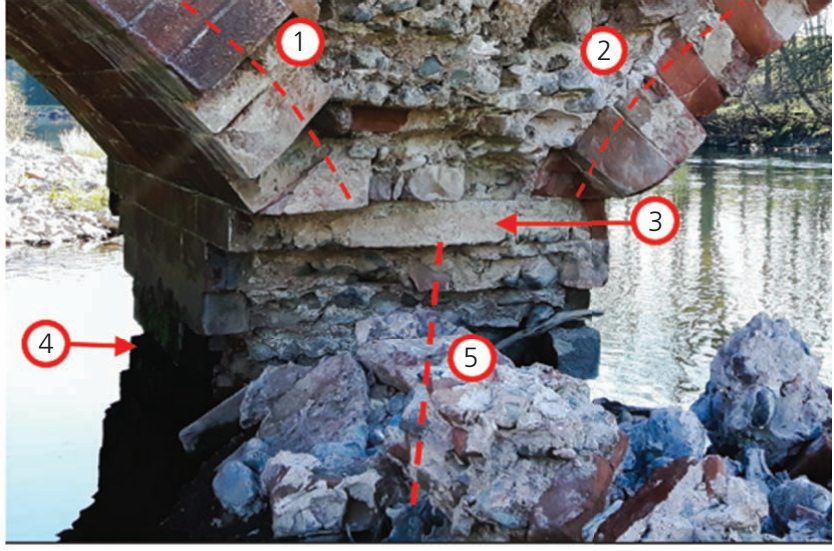

(1) LH arch thrust (2) $\mathrm{RH}$ arch thrust (3) Pier capping slab
(4) Lateral undercutting to LH flank (5) Resolved thrust in pier

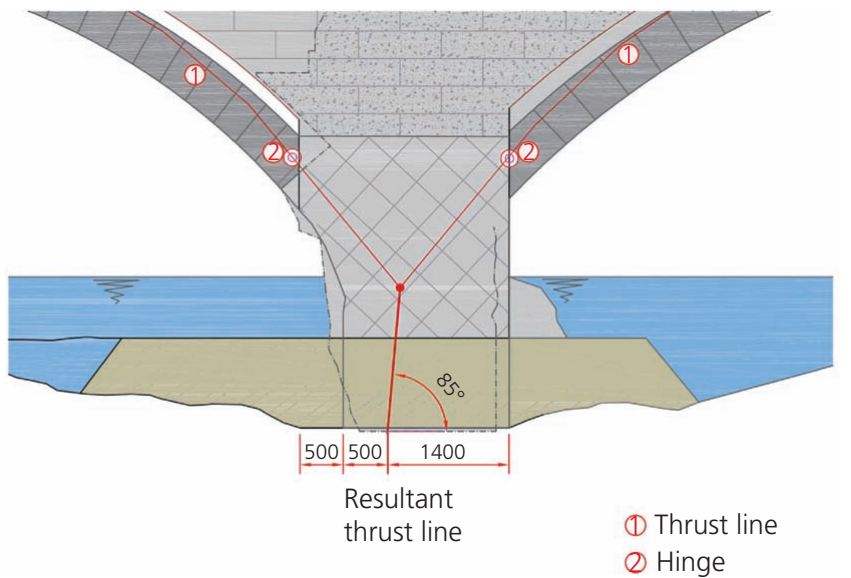

(b)
(2) Hinge

(a)

Figure 5. Thrust and counterthrust force resolution at the pier head. Note the springer hinge lifts from the minimum-thrust position to find stiff support further over the pier head. LH, left hand; RH, right hand. (a) photograph of 'physical cross-section' through pier with structural action superimposed, (b) thrust-line equilibrium assessment of Figure 5(a)

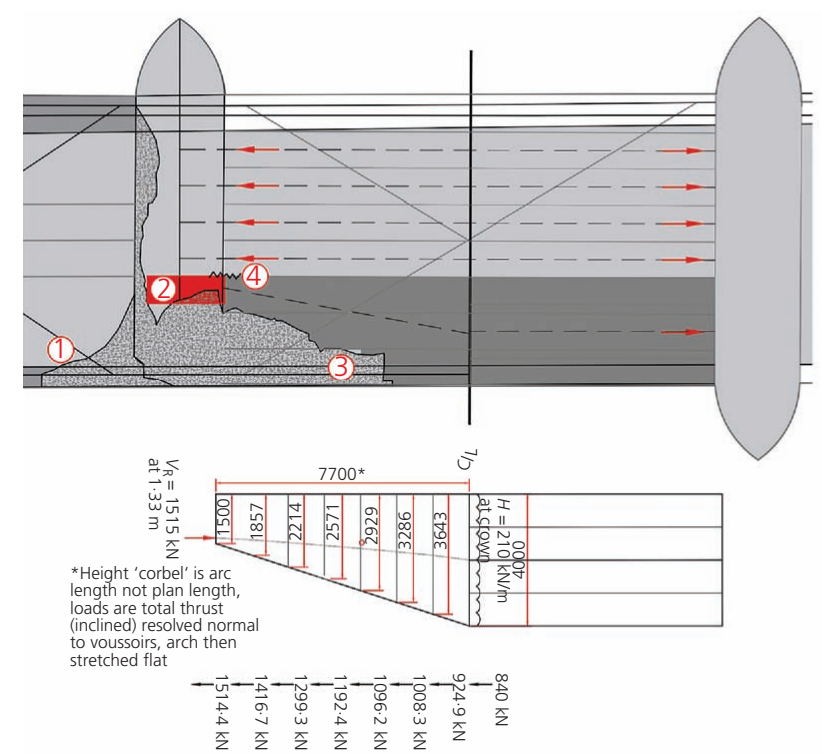

(1) Area locally unstable

(2) Loaded area bears the stress concentration

(2) arising from load redistribution
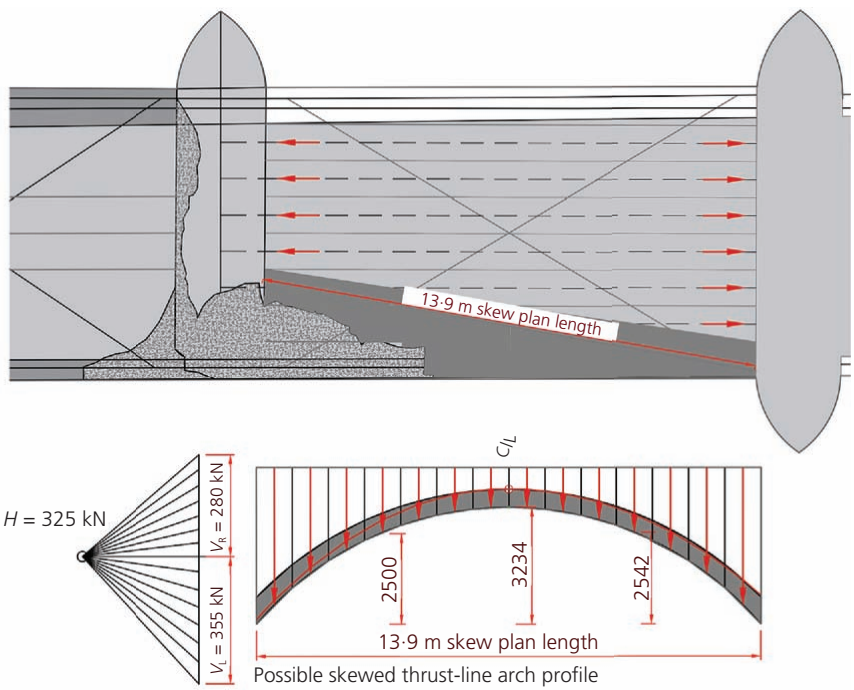

(3) Where the arch has collapsed, a corebelled profile has been left. The metre strips on the opposite (undamaged) side of the crown
still thrust, and their horizontal component is added to the next strip inwards. A reduced vertical load is applied on the damaged crown (4) Coarse vertical crack through pier ashlar facing masonry to
right-hand flank tracking up through arch barrel as indicated

Figure 6. $(a, b)$ Idealisations of the barrel partial collapse and the flow of force in the damaged state. Northern span considered to arch on plan in a similar manner to find support from the damaged pier

over the scour hole on the upstream end; the ashlar pier flank shearing under high load until foundation support was reprovided.

- Tracking the thrust down through the corbel demonstrated a satisfactory possible load path.
- The remaining extent of the arch barrel on the downstream side of the crack was considered to arch 'normally' (approximated as metre-strip lengths between piers).

- An alternative possibility was considered whereby the thrust could skew on plan between the piers, presented in Figure 6(b). 
- The actual position of the thrust is essentially unknowable (Heyman, 1996), but two possible load paths were demonstrated: each could be refined in detail, with a range of stable possibilities in between, so the plan stability was judged to be satisfactory.

- The left-hand (northern) arch on the plan was considered to adopt a similar structural behaviour, and the damage on the plan was accounted for in the overall assessment.

\subsection{Transverse stability}

The stability of the pier was then checked in the transverse direction, bringing in the load concentration from the plan-arching behaviour of the incoming arches and combining this with the undercutting to its upstream end. Again, the behaviour of a masonry corbel was used to interpret the load paths and stability. Figure 7 presents the idealised load diagram.

$$
\begin{aligned}
\sum M_{\text {heel }}= & 0 \\
0= & {[(275 \mathrm{t} \times 2 \cdot 5 \mathrm{~m})+(100 \mathrm{t} \times 4 \mathrm{~m})} \\
& +(100 \mathrm{t} \times 5 \cdot 5 \mathrm{~m})+(80 \mathrm{t} \times 3 \mathrm{~m})]-\left(x \times V_{\mathrm{R}}\right)
\end{aligned}
$$

3. where $V_{\mathrm{R}}=550 \mathrm{t}$ and $x=3.4 \mathrm{~m}$ from the heel (on the edge of the middle third).

4. bearing pressure $=\frac{2 \times R_{\mathrm{V}}}{8}=139 \mathrm{t} / \mathrm{m}$

The pier is $2.4 \mathrm{~m}$ thick, so $139 \mathrm{t} / \mathrm{m} / 2 \cdot 4 \mathrm{~m}=c .575 \mathrm{kN} / \mathrm{m}^{2}$, where the resultant lies on the edge of the middle third of the formation.

The line of resultant thrust was chased down to the likely position of the foundation. At that point, no physical site investigation was achievable (owing to safety implications) although historic borehole $\log$ s indicated the presence of a spread footing on granular riverbed overlying sandstone bedrock. The exact extent of the scour hole was not known, although an estimate of the 'toe' was made. This allowed an approximation of bearing pressure to be made, accounting for the eccentricity of thrust in the pier introduced by the undercutting damage (Figure 7).

The position of the thrust demonstrated that the pier was stable in the transverse direction - that is, not close to the point of overturning despite the damage pattern. If the undercutting were more than half of the pier base, the pier would attempt to overturn

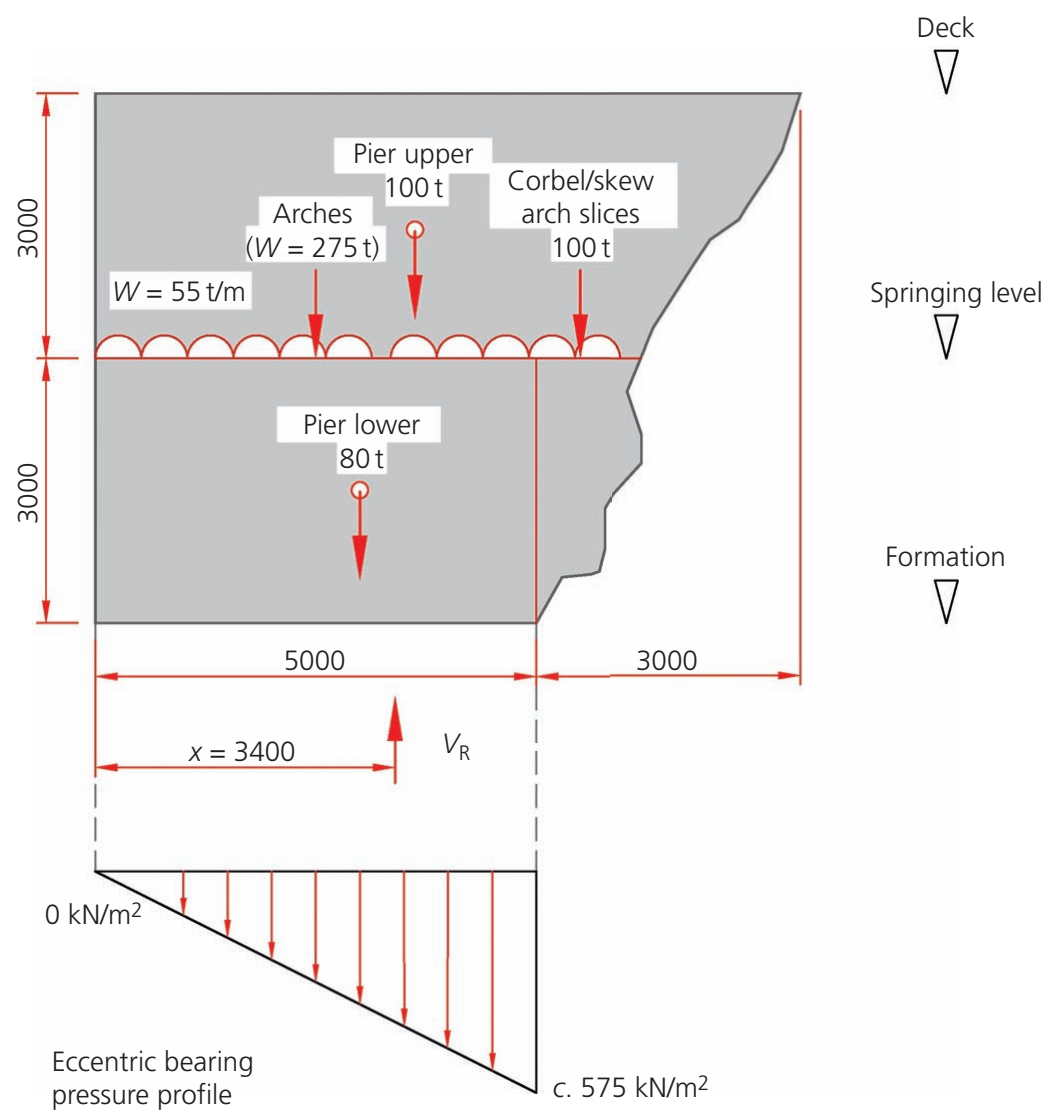

Figure 7. Idealisation of the pier transverse stability and estimated bearing pressure diagram at foundation level 
and would call on the arch barrels to brace it counterclockwise by arching on plan, as at Calva Bridge (Harvey, 2011).

It was difficult to attribute conclusively the upstream tilt of c. $150 \mathrm{~mm}$ to either short-term movement at the time of the undermining scour damage or rotational creep in the 4 months that followed settlement due to load eccentricity. The riverbed comprised medium-dense sand and gravels of a presumed safe bearing capacity of around $200 \mathrm{kN} / \mathrm{m}^{2}$ accounting for the water table at the surface (BSI, 1986), which was clearly exceeded by the applied bearing pressure, manifesting in the significant settlement observed. In comparison, the ultimate bearing capacity of the riverbed was estimated to be in excess of $600 \mathrm{kN} / \mathrm{m}^{2}$ and, although it was being approached, the settlement/tilt of the pier was being monitored in real time, and so it was judged that the risk associated with the overstressed formation was tolerable and was being practically mitigated. The foundation was hence not considered to be at serious risk of overturning failure or gross settlement-related failure under load without plenty of warning exhibited in the masonry substructure.

\subsection{Flat-arching parapet stability}

The overhanging parapet wall was appraised. Clearly, it was flatarching under its own weight (roughly $0.6 \mathrm{t} / \mathrm{m}$, height $0.9 \mathrm{~m}$, flatarching over c. $10 \mathrm{~m}$ span). The horizontal force component of thrust in the plane of the parapet wall was determined using the equation (Heyman, 1996)

$$
\text { 5. } H=\frac{(W \times L)}{8 \times h} \approx 9 \mathrm{t}
$$

where $W=65 \mathrm{kN}, L=10 \mathrm{~m}$ and $h=0.9 \mathrm{~m}$.

The slenderness of the wall under this load was deemed unsafe, and visual signs of distress were evident: the stone blocks were spalling the arrises under high load (point contact between blocks working as arch voussoirs for the first time, splitting into wedge shapes) and attempting to buckle longitudinally.

The justification for its removal to permit safe working was clear; however, it was investigated for its possible role as a brace on plan between left-hand and right-hand arches. Clearly, it was applying $9 \mathrm{t}$ of force into the respective arch spans; however, the key question was whether that was necessary for stability of the wider bridge. The element checks for longitudinal, plan and transverse stability did not require a supplementary bracing force on plan to demonstrate stability, and so the parapet was scheduled for removal.

\section{Assessment of overall stability}

Reconciling element checks for longitudinal, plan, transverse and flat-arching parapet stability, the overall structural behaviour of the bridge in the damaged state was shown to be stable under dead-load conditions provided that further scour of the riverbed could be prevented.
In this way, a complex 3D stability problem was broken down to permit clear assessment of structural behaviour by hand calculations. The calculation assessment aligned with a 'gut feeling' from the visual condition appraisal, which provided the confidence necessary to proceed with the execution of closequarters repair works.

\section{Temporary stabilisation}

A site working enclosure and execution strategy were developed collaboratively with the contractor. This included a cofferdam for diverting the river through the southern span, which was largely unaffected by the damage. The cofferdam comprised an interlocking sheet-piled water stop buttressed by stone-filled bulk bags. Sump pumping with ecologist attendance controlled the seepage and any repeat flood recovery events.

The initial priority was to fill the scour holes. It was recognised that certain aspects of the temporary stabilisation works would not be reversible or retreatable (for conservation engineering philosophy see the discussion by Hume (2014)). A cofferdam around the pier base was created using aggregate-filled bulk bags lifted in safely by using a long-reach plant. This achieved a still pool of water around the pier and controlled concrete placement. The pier was then underpinned by way of a long-reach concrete pump, with underwater-grade concrete suitable for use in potable water in recognition of the special area of conservation river environment. Water quality was monitored throughout by an ecologist.

The parapet arching overhead was then lifted out block by block by means of a hydraulic grab, the masonry units palletised and reclaimed where sound for later reinstatement. The bridge was reassessed, and the movement monitoring confirmed that it remained at rest: the installation of the temporary cutwater and pier shoring works could begin.

Precast concrete 'Lego blocks' were lifted in from distance to form a shutter. Concrete was pumped in from safety, which then engaged the overhanging upstream face of the pier. Once early strength was reached, close-quarters access could be achieved to pack tightly the unsupported ashlar load-bearing facing masonry against the new concrete. Large-section granite rock armour was then used to form a 'falling protection' apron around the pier, and the bridge was left for the winter (Figure 8). Monitoring continued through the use of data loggers until the summer environment agency (EA) working window for the permanent reinstatement works, proving that the temporary stabilisation had arrested any further movement.

\section{Permanent rehabilitation works}

The 'breathing space' break in the contract allowed a detailed study of the bridge's history. This revealed that a similar partial collapse issue had occurred, washing away one of the upstream cutwaters entirely in 1899 (Curwen, 1932). Which cutwater collapsed at that time is not certain, although it seems likely that it would be the same one: repair access would have been limited, 

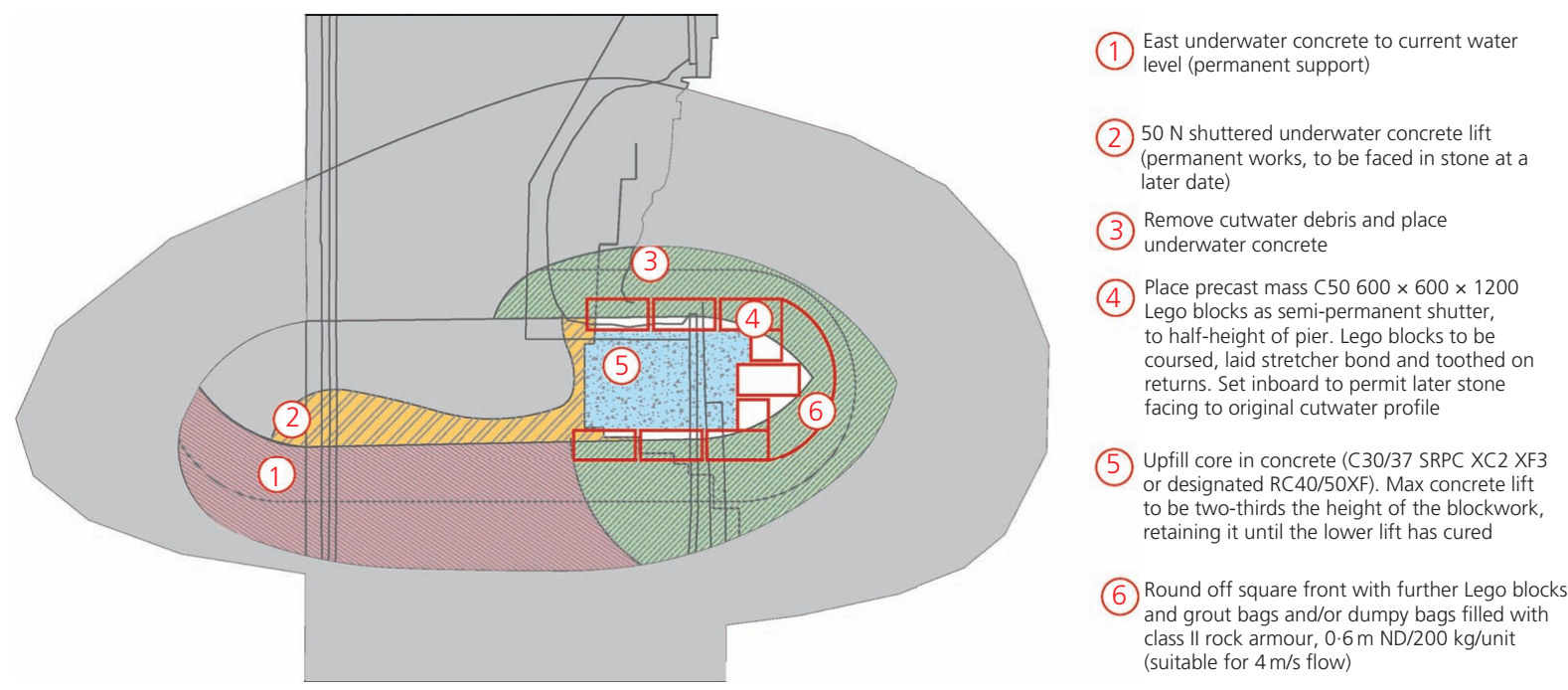

Figure 8. Plan survey on north pier temporary stabilisation works as completed prior to winter 2016. ND, nominal dimension; SRPC, sulfate-resisting Portland cement

making it difficult to achieve a robust repair at that time. Ultimately, it is believed that this led to the residual weakness inherent in the pier, which was then exploited by the Storm Desmond flood event some 120 years on.

The permanent reinstatement works required listed building consent and scheduled ancient monument consent in addition to extension of the EA working permit. From a conservation engineering perspective, there was clearly an imperative to save the bridge as a designated historic asset, but the nature of the repair gave particular focus to the following aspects

- to reinstate the original structural action (an arching gravitymasonry structure) - that is, working with the structure as opposed to against it

- to make faithful use of traditional building skills and materials which would be technically compatible with the existing and replacement masonry fabric

- to reinstate the character and appearance of the bridge, complementing the overall setting (its interrelationship with Brougham Castle to the south bank).

A site investigation was undertaken by way of microcoring down through the piers to confirm the relative positions of the foundation, formation material and bedrock. It demonstrated that the mass stone spread footing was founded on a layer of granular riverbed overlying weathered sandstone bedrock (Figure 9). The root of the problem was hence demonstrated - a scour-susceptible formation.

\section{Remedial design sought to}

- fill the remaining voids in the formation and bridge substructure
- provide a physical barrier against local scour at both upstream and downstream cutwaters

- consolidate loose scour-susceptible formation material (to tackle constriction scour)

- provide a scour-resilient falling-protection apron for resilience to pier flanks.

The remedial detail adopted employed interlocking sheet piles driven to refusal in weathered bedrock, grouting with lowviscosity resin to bind the riverbed material and a rock armour apron. Design principles were informed by the publications by the Construction Industry Research and Information Association (Ciria, 2015, 2006) and Page (1996).

The structural repair of the pier employed techniques presented by Sowden (1990), broadly comprising anchoring of the pier stabilisation concrete into the remaining body of masonry, stitching of the ashlar facing masonry through the pier, grouting of the voided rubble core and reinstating the ashlar stone masonry where lost, including the construction of a new cutwater. The grouting served to help regulate the difference in stiffness between the rough rubble core and the concrete pier fill, avoiding longer-term crack propagation at the interface.

Repair of the partially collapsed arch barrel to the central span required a centring system (Figure 10). This required temporary spread foundations, which were bedded in by the jacks using the weight of the bridge as kentledge. The centring system was used as not only a passive formwork, but also an 'active' support, hydraulically jacking the barrel once the fill was removed to unlock the thrust binding the voussoirs together. This eased the tooth-bonding of the replacement voussoirs into the remaining barrel. The preload in the jacks then was then removed to lock the replacement units into place (Figure 11). 


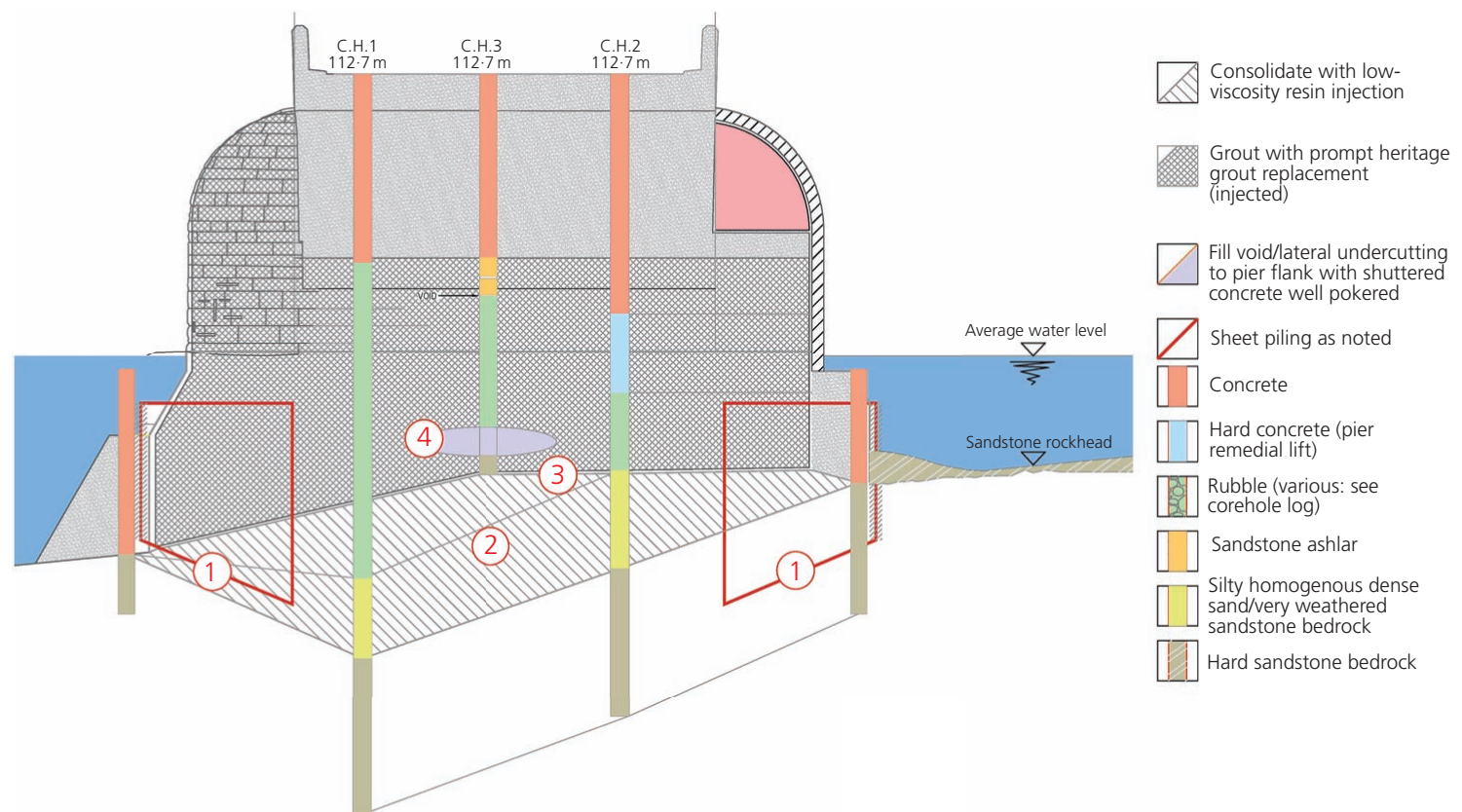
(1) Sheet piles (interlocking) $>1 \mathrm{~m}$ into sandstone bedrock. Sheet pile length varies c. $3-4 \mathrm{~m}$

Armour pier flanks with falling protection (shap granite rock armour and riprap) (4) Fill void/lateral undercutting in pier flank
with shuttered concrete, well pokered

Figure 9. Transverse section through pier showing formation strata and foundation repair work requirements

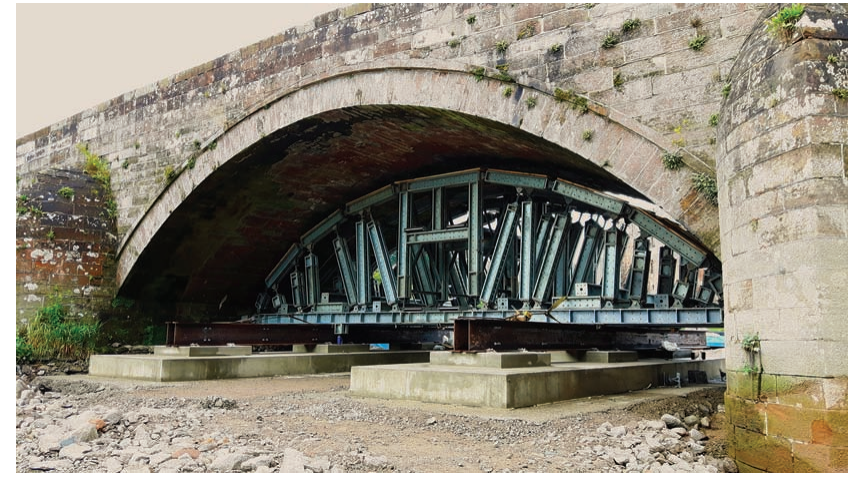

Figure 10. Centring system by temporary works specialist Mabey Contracting being rolled into position on girders on temporary spread foundations formed in the riverbed, viewed from downstream end. Note the hydraulic jacks between the tie-beam and concrete foundation bypassing the girders. The centring truss nodes each have a screw jack to fine-tune the shape up to engage the barrel intrados. Timber folding wedges are then driven into place to engage the masonry fully

Real-time movement monitoring was employed throughout the jacking activities. The piers were laterally braced by the centring system using waling beams off the bottom chord, to permit safe removal of the fill over the central span, keeping the thrusts safely resolved within the piers during the jacking activities.
Spandrel and parapet walls were rebuilt in stone to match the southern span details. A Lytag saddle was placed over the central span to strengthen the arch. Lytag was employed as it had a closer modulus to masonry than dense concrete (Wilmers, 2012). A sawn construction joint was introduced to the concrete saddle at the crown to encourage the formation of the natural hinge at the crown, rather than cracking unpredictably.

\section{Fabric repair and conservation}

Fabric repair was designed with compatible lime mortars (Henry and Stewart, 2012; Pavia, 2006; Wiggins, 2018a, 2018b) in recognition of the various microcontexts at hand, namely

(a) pointing mortar

(b) cyclic wet and dry pier/cutwater mortar

(c) humid superstructure mortar.

For $(a)$ and (b), a hydraulic lime mortar was designed for rapid-set capability in wet conditions while maintaining technical compatibility with the stone masonry, comprising the following constituents

- Vicat Prompt for context (a) - [natural cement]

- Prompt/natural hydraulic lime (NHL) blended hydraulic binder for context $(b)-[\mathrm{C} 3$ hydraulic lime $]$.

The low lime content of the Prompt/NHL hybrid binder was recompensated for through the aggregate, by blending crushed 


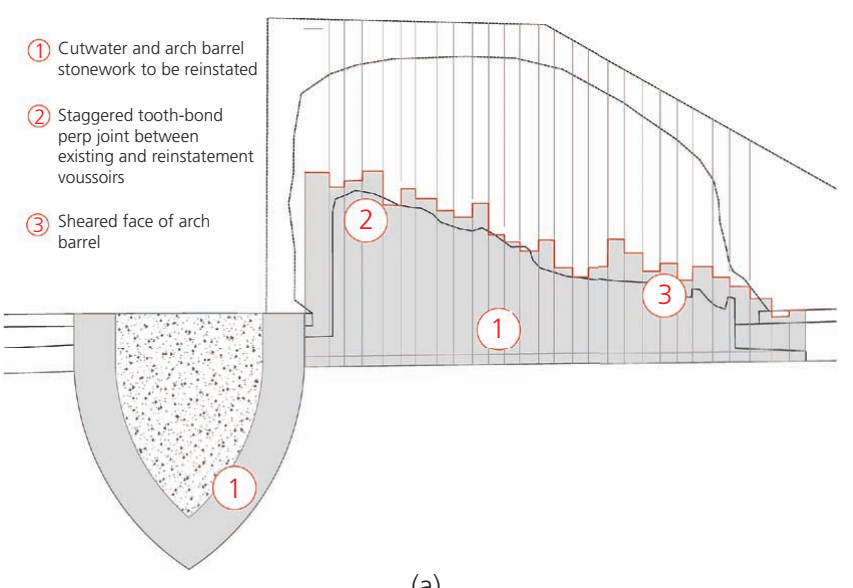

(a)

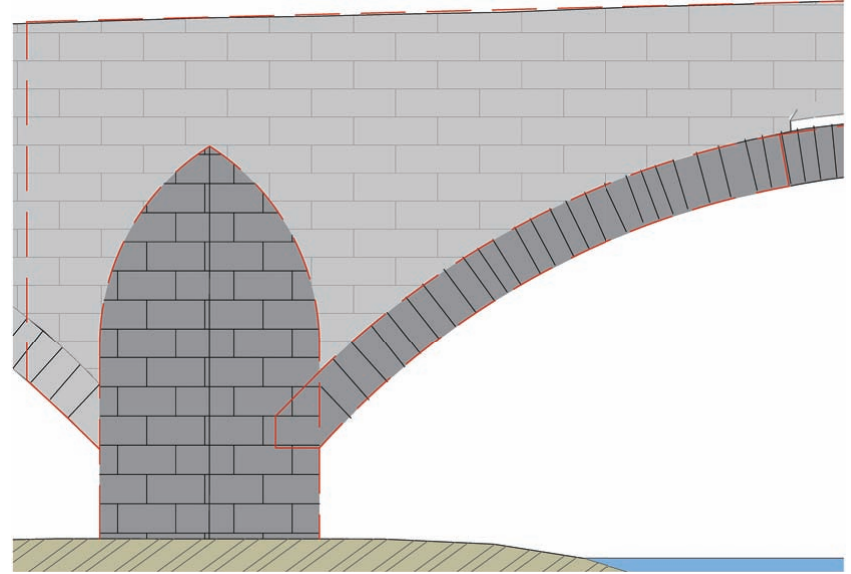

(b)

Figure 11. Arch barrel repair details: (a) plan and (b) sectional views

CL90 limestone into the mix. This achieved a strong, quicksetting, durable mortar in wet conditions, yet with a high uncombined lime content which allows the mortar to dry out and preserve the masonry units (Wiggins, 2018a).

For microcontent (c), a more sacrificial mortar was designed comprising the following mix constituents

- CL90 quicklime/NHL blended hydraulic binder for context (c) - [C2 hydraulic lime].

The mortars were designed to replicate the indigenous hydraulic limes used in bridge-building mortars as recorded in Cowper's UK hydraulic lime classification (Cowper, 1927).

\section{Rehabilitation}

The repair design was demonstrated to support the original $17 \cdot 5 \mathrm{t}$ restricted access using the Archie-M thrust-line bridge assessment program. The program uses graphic statics to interpret masonry bridge behaviour under dead and live loads including rolling point loads (e.g. lorry axle in the Highways Agency (2001) standard). Figure 12 presents a graphic of the thrust-line feedback under a rolling point load at an onerous quarter-point position.

The final stage in rehabilitation was to undertake a load test to the procedure outlined in the Highways Agency (1994) standard, broadly comprising a loaded aggregate lorry set to position its rear axle over defined points on the bridge (e.g. pier head, arch quarter-point, crown.) while a digital theodolite monitored preset targets positioned on the arch barrel over time. The test is a bit of a 'blunt instrument' (it measures the face voussoirs of the barrel only); however, it was instructive insofar as appraising deformation under a given load for the repaired area. The repaired pier recorded zero deformation under load. The arch barrel initially recorded some $8 \mathrm{~mm}$ settlement of the first voussoir bearing on the embedded skewback and around $5 \mathrm{~mm}$ at the quarter-point of the rebuilt barrel section.

The deformation stopped after the first 5 min loading period and remained constant under the load for the remaining $10 \mathrm{~min}$ at each

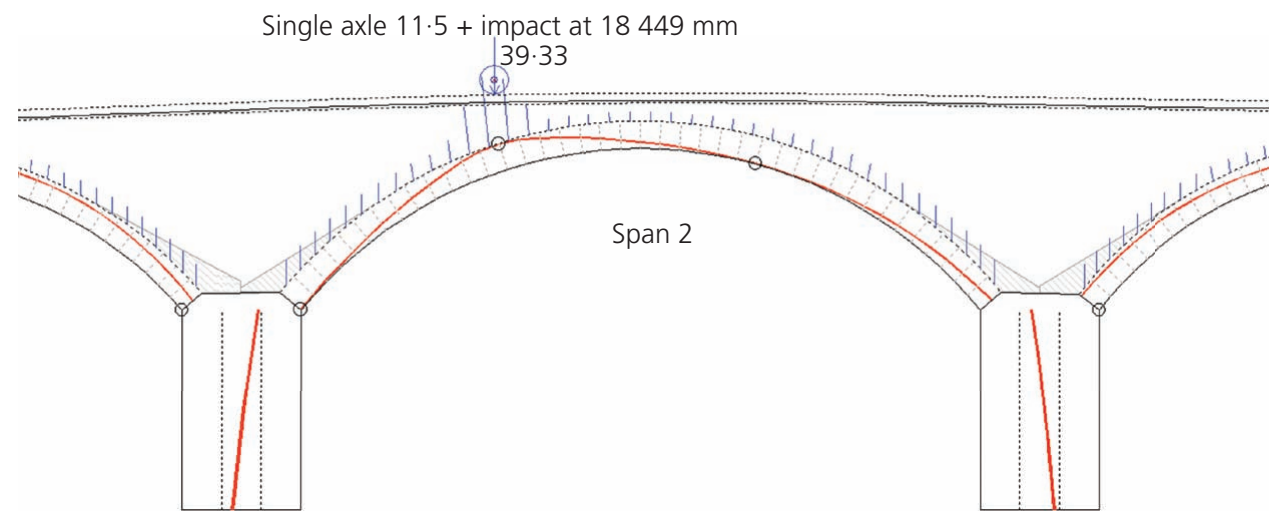

Figure 12. Central span under quarter-point loading with passive response from unloaded arches 
Engineering History and Heritage

Volume 172 Issue EH1
Rehabilitation of Brougham Castle

Bridge, UK

Wiggins, Mudd and Healey

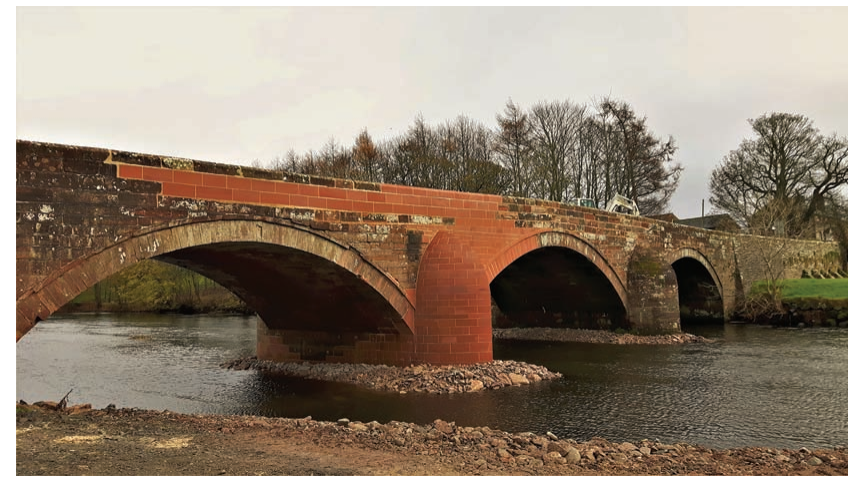

Figure 13. The rehabilitated bridge opened to traffic following a successful load test

location. A repeat of the load test was performed to investigate the initial response of the bridge to loading, and only nominal deformation was observed, importantly being elastic in nature (rebounding when the load was removed). The initial plastic settlement was hence determined to record the 'bedding-in' of the new work: by contrast, the pier itself exhibited zero deformation, which confirmed that the rebuilt skewback had bedded down into the pier. The repeat load test confirmed successful rehabilitation, and the bridge reopened to traffic (Figure 13).

\section{Summary and conclusions}

n The structural behaviour of traditional masonry is an assemblage of dry-jointed masonry units drawing stability from its weight and geometry which governs thrust and counterthrust.

- Thrust-line equilibrium analysis was used to interpret rationally the possible load paths remaining in a seriously damaged structure.

- A complex 3D problem was broken down for assessment in two dimensions by traditional hand methods, the findings of which aligned with the observed structural pathology and gut feeling of the engineer.

- A phased approach to working proximity was successfully adopted, using real-time monitoring of structural movement, to ensure total workforce safety.

- A distinctive local landmark and heritage asset was saved from collapse and preserved in line with conservation engineering principles of compatible intervention, where the form, appearance and character of the original bridge were preserved.

\section{REFERENCES}

BSI (1986) BS 8004:1986: Code of practice for foundations. BSI, London, UK.

BSI (2007) BS EN 1993-5:2007: Eurocode 3: Design of steel structures. Piling. BSI, London, UK

BSI (2009) BS 5228-2:2009: Code of practice for noise and vibration control on construction and open sites. BSI, London, UK.
Cassinello M (2006) Effect of mortar joint thickness on deformability in medieval stone walls. Materiales de Construcción 56(284): 69-80.

Ciria (Construction Industry Research and Information Association) (1992) Ground-borne Vibrations Arising from Piling. Ciria, London, UK, Technical Note 142.

Ciria (2006) Masonry Arch Bridges: Condition Appraisal and Remedial Treatment. Ciria, London, UK, C656.

Ciria (2015) Manual on Scour at Bridges and Other Hydraulic Structures, 2nd edn. Ciria, London, UK.

Cowper AD (1927) Lime and Lime Mortars. Donhead, Shaftesbury, UK Cumbrian Stone (2016) Bowscar Sandstone. Cumbrian Stone, Penrith, UK. See https://cumbrianstone.co.uk/ (accessed 31/08/2017).

Curwen JF (1932) Parishes (West Ward): St Ninian, Brougham. In The Later Records Relating to North Westmorland or the Barony of Appleby. Titus Wilson and Son, Kendal, UK. See https://www.britishhistory.ac.uk/n-westmorland-records/vol8/pp278-290\#h3-0011 (accessed 09/10/2018).

Harvey W (2011) Bridge of the Month No6 June 2011: Calva Bridge, Workington. Obvis and Bill Harvey Associates Ltd, Exeter, UK. See http://billharvey.typepad.com/BridgeOfTheMonth/Calva.pdf (accessed 09/10/2018).

Harvey W (2012a) The Coy Mistress - a view of masonry behaviour. The Structural Engineer, February, pp. 25-31.

Harvey W (2012b) Stiffness and damage in masonry bridges. Proceedings of the Institution of Civil Engineers - Bridge Engineering 165(3): $127-134$.

Harvey W (2013) A spatial view of the flow of force in masonry bridges. Proceedings of the Institution of Civil Engineers - Bridge Engineering 166(1): 51-58, https://doi.org/10.1680/bren.11.00026.

Henry A and Stewart J (2012) Mortars, Plaster \& Renders. English Heritage, Swindon, UK.

Heyman J (1969) The safety of masonry arches. International Journal of Mechanical Sciences 11: 363-365.

Heyman J (1982) The Masonry Arch. Ellis Horwood, Hemel Hempstead, UK.

Heyman J (1996) Arches, Vaults and Buttresses. Variorum, Aldershot, UK.

Highways Agency (1994) BA 54/94: Load testing for bridge assessment. Highways Agency, Guildford, UK.

Highways Agency (2001) BD 37/01: Loads for highway bridges. Highways Agency, Guildford, UK.

Historic England (2018a) Brougham Castle Bridge. Historic England, London, UK. See https://historicengland.org.uk/listing/the-list/listentry/1145357 (accessed 16/08/2018).

Historic England (2018b) Brougham Roman Fort (Brocavum) and Civil Settlement and Brougham Castle. Historic England, London UK. See https://historicengland.org.uk/listing/the-list/list-entry/1007186 (accessed 16/08/2018).

Hume L (2014) The philosophy of conservation engineering. In Structures and Construction in Historic Building Conservation (Forsyth M (ed.)) Wiley-Blackwell, Chichester, UK, pp. 12-18.

Mathews R and Hardman M (2017) Lessons learnt from the December 2015 flood event in Cumbria, UK. Proceedings of the Institution of Civil Engineers - Forensic Engineering 170(4): 165-178, https://doi. org/10.1680/jfoen.17.00009.

McIntyre F (2018) Tech excellence: Brougham Old Bridge repairs. New Civil Engineer, 14 March, pp. 50-52. See https://www. newcivilengineer.com/tech-excellence/tech-excellence-brougham-oldbridge/10029147.article (accessed 15/03/2018).

Page J (1996) A Guide to Repair and Strengthening of Masonry Arch Highway Bridges. Transport Research Laboratory, Wokingham, UK.

Pavia S (2006) Repair mortars for masonry bridges. In Bridge and Infrastructure Research in Ireland: Symposium 2006 (Nuallain N, O'Connor A and Gavin K (eds)). Trinity College, Dublin, pp. $183-190$ 
Ruddock T (2009) Arch Bridges and Their Builders 1735-1835. Cambridge University Press, Cambridge, UK.

Sowden AM (1990) The Maintenance of Brick and Stone Masonry Structures. E. \& F.N. Spon, Cambridge, UK.

Wiggins DE (2018a) Masonry bridges and the importance of lime. In The Building Conservation Directory 2018 (Taylor J (ed.)), 25th edn. Cathedral Communications, Wiltshire, UK, pp. 51-54.
Wiggins DE (2018b) Hot-mixed Lime Mortars: Microstructure and Functional Performance. Historic Environment Scotland, Edinburgh, UK, Technical Paper 27.

Wilmers W (2012) Restoration of masonry arch bridges. Proceedings of the Institution of Civil Engineers - Bridge Engineering 165(3): 135-146, https://doi.org/10.1680/bren.11.00011.

\section{How can you contribute?}

To discuss this paper, please email up to 500 words to the editor at journals@ice.org.uk. Your contribution will be forwarded to the author(s) for a reply and, if considered appropriate by the editorial board, it will be published as discussion in a future issue of the journal.

Proceedings journals rely entirely on contributions from the civil engineering profession (and allied disciplines). Information about how to submit your paper online is available at www.icevirtuallibrary.com/page/authors, where you will also find detailed author guidelines. 